\title{
NOTE
}

\section{Effect of feeding on cadmium bioaccumulation in the echinoid Paracentrotus lividus (Echinodermata)}

\author{
Michel Warnau ${ }^{1,2, *}$, Jean-Louis Teyssié ${ }^{1}$, Scott W. Fowler ${ }^{1}$ \\ 'IAEA Marine Environment Laboratory, PO Box 800, MC-98012 Monaco \\ ${ }^{2}$ Laboratoire de Biologie marine (CP 160-15), Université Libre de Bruxelles, 50 av. F. D. Roosevelt, B-1050 Bruxelles, Belgium
}

\begin{abstract}
Echinoids Paracentrotus lividus (Lamarck, 1816) were contaminated under laboratory conditions with $\mathrm{Cd}$ (as $\mathrm{CdCl}_{2}$ ) either from sea water or from both sea water and food (Posidonia oceanica leaves) simultaneously. The experimental results showed that $\mathrm{Cd}$ bioaccumulation in the digestive tract wall and Aristotle's lantern of echinoids contaminated via both sea water and food was significantly less (as much as $50 \%$ ) than when echinoids accumulated Cd from sea water only. The opposite trend was observed for the coelomic fluid of these echinoids. These observations suggest that food containing high Cd concentrations (1) reduces the efficiency of the digestive tract wall and Aristotle's lantern in taking up $\mathrm{Cd}$ from sea water, and (2) could enhance metal depurative activity of the echinoid coelom.
\end{abstract}

KEY WORDS: Cadmium - Bioaccumulation - Metabolism Paracentrotus lividus

Several recent metal flux studies have focused on examining the relative importance of sea water and food as routes for metal bioaccumulation by marine organisms (see e.g. Guary et al. 1982, Nakamura et al. 1986, Bouquegneau \& Joiris 1988, Bremer et al. 1990, Nolan et al. 1992). This aspect has generally been assessed by comparing results from experiments in which the contamination from sea water and food were studied separately. Only a few studies have taken into account mixed-source contamination, i.e. uptake via both sea water and food (Fowler et al. 1981, Borchardt 1983, Carvalho \& Fowler 1994). Unfortunately, the latter generally do not include parallel investigations employing separate exposure modes. Based on results from a recent field study on $\mathrm{Cd}$ fluxes through the echinoid Paracentrotus lividus (Warnau et al. 1995), a comparison between the different exposure modes is however of particular interest.

•E-mail: mwarnau@ulb.ac.be
Warnau et al. (1995) reported that the different body compartments of echinoids exposed to $\mathrm{Cd}$ via both sea water and food together contained lower $\mathrm{Cd}$ concentrations than corresponding compartments of echinoids exposed to $\mathrm{Cd}$ via sea water only. These authors suggested that high metal concentrations in the food could trigger a net decrease of Cd uptake from sea water, presumably through an increase of both excretion and mucus production by the echinoids. However, since stable $\mathrm{Cd}$ was the only contaminant for both the sea water and food pathways, the experimental procedure of Warnau et al. (1995) did not allow distinction between contaminant source terms (water vs food) once $\mathrm{Cd}$ was incorporated by the echinoids. These authors were consequently not able to test their hypothesis that echinoids actually accumulated less Cd from sea water.

The present work further investigates the effect of feeding on the uptake of $\mathrm{Cd}$ by Paracentrotus lividus. The methodology followed here was adapted from Warnau et al. (1995) in order to study similar experimental conditions while improving data comparability. For this reason the different exposure modes were studied simultaneously in the same experimental enclosure. In addition, both stable and radioactive $\mathrm{Cd}$ were used as contaminants: food was contaminated with stable Cd only, while sea water was contaminated with both stable and radioactive $\mathrm{Cd}$. The use of radioanalytical techniques thereby allowed tracing separately the uptake of $\mathrm{Cd}$ directly from sea water.

Materials and methods. Organisms and laboratory conditioning: Individual echinoids, Paracentrotus lividus (Lamarck, 1816), and shoots of the phanerogam Posidonia oceanica (L.) Delile were collected during May 1994 by SCUBA diving between 5 and $10 \mathrm{~m}$ depth in the $P$. oceanica meadow near 'La Pointe des Douaniers', Cap d'Ail, France. The echinoids and phanerogams were subsequently acclimatized to labo- 
ratory conditions (closed circuit aquaria, constantly aerated; salinity: $38 \%$; $16.5 \pm 0.5^{\circ} \mathrm{C}$; light/dark cycle: $12 \mathrm{~h} / 12 \mathrm{~h}$ ) for $10 \mathrm{~d}$ prior to experimentation.

Metal, radiotracer, and radioanalysis: Experimental contaminations involved the use of stable $\mathrm{Cd}$ (as $\mathrm{CdCl}_{2}$; Merck, synthesis quality) and a radiotracer, ${ }^{109} \mathrm{Cd}$ (as ${ }^{109} \mathrm{CdCl}_{2}, \mathrm{~T}_{1 / 2}=462.6 \mathrm{~d}$; Amersham, carrier free). Stock solutions of the metal and radiotracer were prepared in $0.1 \mathrm{M} \mathrm{HCl}$. Radioactivities were determined using a high-resolution $\gamma$-spectrometry system consisting of a coaxial germanium $N$ type detector (EGNC 33-195-R, Intertechnique) connected to a multichannel analyser and a personal computer with spectral analysis software (Intergamma, Intertechnique). ${ }^{109} \mathrm{Cd} \gamma$-emissions were detected at $88.034 \mathrm{keV}$. The radioactivity of the samples was quantified by comparison with known standards of appropriate geometry and corrected for background and physical decay.

Experimental procedure: One polyvinylchloride aquarium (capacity 4 l) was divided into 2 sections with a $5 \mathrm{~mm}$ mesh polystyrene grid which allowed sea water to flow through both parts. Sea water was contaminated with $20 \mu \mathrm{g}$ stable $\mathrm{Cd} \mathrm{l}^{-1}(250 \mu \mathrm{l}$ stock solution added $\left.\mathrm{l}^{-1}\right)$, spiked with $4.3 \mathrm{kBq}{ }^{109} \mathrm{Cd} \mathrm{l}^{-1}(7.5 \mu \mathrm{l}$ stock solution added $\mathrm{l}^{-1}$ ), and allowed to equilibrate for about $2 \mathrm{~h}$ before use. The $\mathrm{pH}$ of the radio-labelled sea water remained unchanged at 8.06. One group of 3 echinoids was then placed in each section. Echinoid ambital diameter was $45 \pm 3 \mathrm{~mm}$ (mean $\pm \mathrm{SD}$ ) for Group I individuals and $47 \pm 2 \mathrm{~mm}$ for Group II individuals.

All echinoids were fed ad libitum on leaves of Posidonia oceanica, the echinoids' main food source in these seagrass meadows (Nedelec \& Verlaque 1984). (All P. oceanica leaves used in the present experiment bore epiphytes.) Leaves which Group I echinoids ingested were previously contaminated with $20 \mu \mathrm{g}$ stable $\mathrm{Cd} \mathrm{I}^{-1}$ for $15 \mathrm{~d}$. The stable $\mathrm{Cd}$ concentrations within contaminated leaves were not measured; however, based on identical experimental contamination procedures employed in similar experiments (Warnau et al. 1995, G. Ledent, M. Warnau, A. Temara \& Ph. Dubois et al. unpubl.), it was assumed that the leaves contained Cd concentrations of ca $9 \mu \mathrm{g} \mathrm{g}^{-1}$ wet wt, which is about 30 times higher than that of uncontaminated leaves. Group II echinoids were fed uncontaminated leaves. These leaves were previously maintained for $15 \mathrm{~d}$ under the same conditions as were contaminated leaves, but without the stable $\mathrm{Cd}$ additions. The experimental conditions for the 2 treatments are shown in Table 1.

The sea water media (with both stable and radioactive $\mathrm{Cd}$ ) and leaf rations (of both groups) were renewed daily in the evening (echinoids feed mainly during the night; Dance 1987, pers obs.) in order to
Table 1, Paracentrotus lividus. Experimental conditions for $\mathrm{Cd}$ contamination experiments. Group I: echinoids exposed to $\mathrm{Cd}$ via both sea water and food (Posidonia oceanica leaves); Group II: echinoids exposed to $\mathrm{Cd}$ via sea water only

\begin{tabular}{|c|c|c|}
\hline \multicolumn{2}{|r|}{ Group I } & Group II \\
\hline Sea w & \multicolumn{2}{|c|}{$\begin{array}{c}20 \mu \mathrm{g} \text { stable } \mathrm{Cd} \mathrm{l}^{-1} \\
4.3 \mathrm{kBq}{ }^{109} \mathrm{Cd} \mathrm{l}^{-1}\end{array}$} \\
\hline Food & $\begin{array}{c}\text { Leaves contami- } \\
\text { nated for } 15 \mathrm{~d} \text { with } \\
20 \mu \mathrm{g} \text { stable } \mathrm{Cd} \mathrm{I}^{-1} \\
\text { (no }{ }^{109} \mathrm{Cd} \text { ) }\end{array}$ & $\begin{array}{c}\text { Leaves maintained } \\
\text { for } 15 \mathrm{~d} \text { in sea water } \\
\text { containing neither stable } \\
\mathrm{Cd} \text { nor }{ }^{109} \mathrm{Cd}\end{array}$ \\
\hline
\end{tabular}

(1) maintain the stable $\mathrm{Cd}$ concentration and ${ }^{109} \mathrm{Cd}$ activity in sea water as constant as possible, and (2) reduce possible ${ }^{109} \mathrm{Cd}$ uptake by Posidonia oceanica leaves as much as possible. Radioactivity of ${ }^{109} \mathrm{Cd}$ in the water and leaves of the 2 groups were checked daily before and after each renewal in order to determine the time-integrated activity in the water and possible radiolabelling of leaves, respectively.

During the exposure time $(10 \mathrm{~d}),{ }^{109} \mathrm{Cd}$ radioactivity in each living echinoid was whole-body counted every second day. At the end of the experiment, all echinoids were sacrificed and dissected. The body wall, Aristotle's lantern, digestive tract wall (after removal of the gut contents), gonads, and coelomic fluid were separated, weighed (wet wt), and their ${ }^{109} \mathrm{Cd}$ content measured. Counting times were adapted to obtain counting rates with relative propagated errors $\leq 5 \%$. Counting times were $5 \mathrm{~min}$ for wholebody radioanalysis and ranged from 5 to $60 \mathrm{~min}$ for dissected tissues and organs, sea water, and seagrass leaves.

Data analysis: Uptake of ${ }^{109} \mathrm{Cd}$ was expressed by the change in the concentration factor (CF) over time. $\mathrm{CF}$ was calculated by dividing radioactivity in echinoids or body compartments ( $\mathrm{Bq} \mathrm{g}^{-1}$ wet $\mathrm{wt}$ ) by time-integrated radioactivity in sea water $\left(\mathrm{Bq} \mathrm{g}^{-1}\right)$. Whole-body uptake of ${ }^{109} \mathrm{Cd}$ by echinoids contaminated either from sea water alone or from both sea water and food were fitted using simple linear regressions. Linearity was tested by the linearity test for regression with replication. Difference between slopes of the regression equations was tested by the bilateral $t$-test ( $Z$ ar 1984). Differences between the CF in each echinoid body compartment after $10 \mathrm{~d}$ of exposure were tested by the unilateral t-test. One-way analysis of variance (ANOVA) was used to test (1) variations with time of ${ }^{109} \mathrm{Cd}$ activity measured in the different rations of Posidonia oceanica leaves after a $24 \mathrm{~h}$ period in the aquarium, and (2) differences between activity measured in $P$. oceanica leaves from the 2 sections of the aquarium (Zar 1984). 
Results. After a $24 \mathrm{~h}$ period in the aquarium as echinoid food, Posidonia oceanica leaves slightly accumulated ${ }^{109} \mathrm{Cd}$, regardless of whether or not they were previously contaminated with stable Cd (data not shown). ANOVA did not show any significant differences $(\alpha=0.05)$ in ${ }^{109} \mathrm{Cd}$ labelling between $P$. oceanica leaves that were previously contaminated (Group I) and those that were not (Group II). This indicated that all leaves (contaminated or not) took up Cd similarly; hence, stable $\mathrm{Cd}$ uptake by leaves previously contaminated had not reached a steady-state equilibrium. In addition, ANOVA did not show any significant differences $(\alpha=0.05)$ in ${ }^{109} \mathrm{Cd}$ labelling between the successive $P$. oceanica leaf rations used in a same section of the experimental aquarium. Food may therefore have contributed slightly to the total ${ }^{109} \mathrm{Cd}$ activity measured in echinoids during the experiments; this contribution was however identical for the 2 echinoid groups considered.

Whole-body ${ }^{109} \mathrm{Cd}$ uptake kinetics in echinoids for the 2 investigated treatments (Group I: Cd exposure via both food and sea water; Group II: Cd exposure via sea water only) were both accurately fitted by simple linear regressions ( $p$ linearity $<0.05$ ) (Fig. 1). Slopes of the 2 regression equations were not significantly different (bilateral $t$-test, $\alpha=0.05$ ).

After $10 \mathrm{~d}$ of exposure, the echinoids from the 2 groups were sacrificed and dissected. The ${ }^{109} \mathrm{Cd}$ concentration factors (CF) in their body compartments are given in Table 2. Statistical comparisons of the CF in digestive tract wall, Aristotle's lantern, and coelomic fluid indicated significant differences in ${ }^{109} \mathrm{Cd}$ accumulation between echinoids from Groups I and II (unilateral $t$-test, $\alpha=0.05$ ). The ${ }^{109} \mathrm{Cd} \mathrm{CF}$ in digestive tract wall and Aristotle's lantern was 30 to $50 \%$ lower in echinoids which had ingested contaminated leaves, while the ${ }^{109} \mathrm{Cd} \mathrm{CF}$ in the coelomic fluid in those echinoids was enhanced by a factor of 2 .

Discussion. The ${ }^{109} \mathrm{Cd}$ concentration factor (CF) was significantly lower (as much as $50 \%$ ) in the digestive tract wall and Aristotle's lantern of Paracentrotus lividus exposed to the metal in both sea water and food
Concentration factor

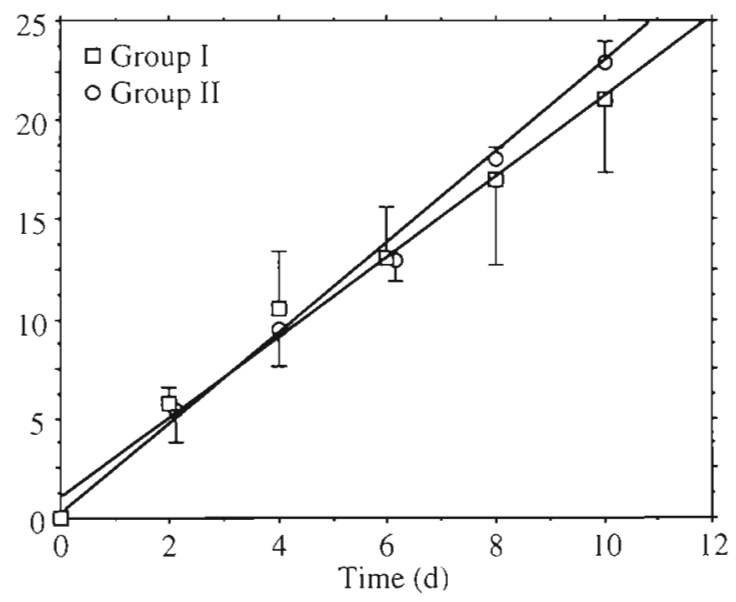

Fig. 1. Paracentrotus lividus. Whole-body uptake kinetics of ${ }^{109} \mathrm{Cd}$ (mean concentration factor $\pm \mathrm{SD} ; \mathrm{n}=3$ ) in echinoids exposed to $\mathrm{Cd}$ via sea water $\left(20 \mu \mathrm{g}\right.$ stable $\mathrm{Cd} \mathrm{l}^{-1}$ and $4.3 \mathrm{kBq}$ ${ }^{109} \mathrm{Cd} \mathrm{l}^{-1}$ ) and fed on Posidonia oceanica leaves previously contaminated for $15 \mathrm{~d}$ with $20 \mu \mathrm{g}$ stable $\mathrm{Cd} \mathrm{l}^{-1}$ (Group I) or fed on uncontaminated leaves (Group If). Equations of the linear regressions are (1) Group I: $C F=1.11+2.02 t\left(R^{2}=0.89, p \leq\right.$ $0.0001)$ and (2) Group II: $C F=0.36+2.31 t\left(R^{2}=0.93, p \leq\right.$ $0.0001)$; where $t=$ time $(\mathrm{d})$

than when sea water was the sole source of elevated $\mathrm{Cd}$ exposure. The body wall and gonads showed a similar decreasing trend, though the differences were not statistically significant. This was probably a result of the short duration of the experiment (10 d) since Warnau et al. (1995) actually observed a significant decrease of $\mathrm{Cd}$ uptake in these compartments after $18 \mathrm{~d}$ of exposure. In contrast, the ${ }^{109} \mathrm{Cd} \mathrm{CF}$ in coelomic fluid from echinoids contaminated from both sea water and food was twice that of echinoids exposed to elevated $\mathrm{Cd}$ in sea water only. The ${ }^{109} \mathrm{Cd} \mathrm{CF}$ decrease was not observed when whole-body uptake was considered. This was due to the fact that the 3 body compartments which did show significant variation in ${ }^{109} \mathrm{Cd} \mathrm{CF}$ are either too small (negligible contribution of digestive tract wall and Aristotle's lantern to total echinoid

Table 2. Paracentrotus Lividus. Concentration factor (mean $\mathrm{CF} \pm \mathrm{SD} ; \mathrm{n}=3$ ) of ${ }^{109} \mathrm{Cd}$ in echinoid body compartments after $10 \mathrm{~d}$ of exposure to $20 \mu \mathrm{g}$ stable $\mathrm{Cd} 1^{-1}$ and $4.3 \mathrm{kBq}{ }^{109}{\mathrm{Cd}{ }^{-1}}^{-1}$ via sea water and to a diet (Posidonia oceanica leaves) previously contaminated for $15 \mathrm{~d}$ with $20 \mu \mathrm{g}$ stable $\mathrm{Cd}^{-1}$ (Group I) or not contaminated with stable Cd (Group II). p: probability of the unilateral $t$-test

\begin{tabular}{|lccccc|}
\hline Compartments & \% of total echinoid wet wt & CF Group I & CF Group II & p & Feeding effect on CF \\
\hline Body wall & $48 \pm 8.7$ & $39 \pm 16$ & $47 \pm 6.1$ & 0.24 & None \\
Aristotle's lantern & $4.4 \pm 0.8$ & $9.3 \pm 1.5$ & $12 \pm 1.9$ & 0.04 & Decrease \\
Digestive tract wall & $2.5 \pm 0.9$ & $43 \pm 21$ & $90 \pm 13$ & 0.02 & Decrease \\
Gonads & $1.1 \pm 0.8$ & $7.1 \pm 4.0$ & $10 \pm 4.6$ & 0.25 & None \\
Coelomic fluid & $44 \pm 6.9$ & $1.3 \pm 0.3$ & $0.7 \pm 0.3$ & 0.04 & Increase \\
\hline
\end{tabular}


wet wt) or do not concentrate sufficient ${ }^{109} \mathrm{Cd}$ (very low CF in coelomic fluid) to influence significantly the whole-body uptake kinetics.

Our experimental results are in accordance with those of Warnau et al. (1995) who first suggested a supressive effect of feeding on Cd uptake by Paracentrotus lividus. Moreover, our findings demonstrate that the net decrease of Cd uptake observed in echinoids exposed to $\mathrm{Cd}$ via both sea water and food is a direct result of lower Cd uptake from sea water. Indeed, the experiment was designed in such a way that sea water constituted the sole significant source of ${ }^{109} \mathrm{Cd}$. According to Warnau et al. (1995), a decrease of Cd uptake from sea water could be due to enhanced echinoid excretion which would increase metal elimination, and to increased mucus production which would decrease metal bioavailability. These combined processes could be triggered by the elevated $\mathrm{Cd}$ concentration present in the contaminated Posidonia oceanica leaves upon which echinoids were feeding. No evidence against this hypothesis was found in the present study. Nevertheless, the occurrence of a significantly higher ${ }^{109} \mathrm{Cd} C F$ in the coelomic fluid (a body compartment that was not previously investigated) of echinoids accumulating $\mathrm{Cd}$ from both sea water and food suggests that the coelomic fluid and/or its cellular components (coelomocytes) could also be involved in the physiological response to contamination. This is in accordance with Pelletier \& Larocque (1987) who have previously suggested coelomocyte participation in a $\mathrm{Hg}$ detoxification process occurring in the asteroid Leptasterias polaris exposed to contaminated food.

Studies of heavy metal fluxes through marine organisms are an important tool in ecotoxicology. Indeed, they allow the assessment of the susceptibility of an organism to accumulate a given metal, to be impacted by this metal, or to constitute a source of contamination for higher trophic levels (see e.g. Bouquegneau \& Joiris 1988, Depledge \& Rainbow 1990, Besten et al. 1991). Flux studies are also a preliminary requirement to characterize bioindicator species to be selected for environmental monitoring and quality assessments (Phillips 1976, Depledge \& Rainbow 1990). The usefulness of such experiments necessitates obtaining key kinetics parameters such as uptake and retention rates, as well as the maximum contaminant concentration incorporated. In the present work it was shown that, in the case of Cd contamination of the echinoid Paracentrotus lividus, the ingestion of Cd-contaminated food might interact with metal absorption from sea water and its subsequent metabolism. In our study, such an interaction resulted in the decrease of the $\mathrm{Cd}$ CF in different body compartments. This observation indicates that mixed-source exposures should not be neglected in metal flux studies, in particular when studying acute contamination that generally involves the use of relatively high contaminant concentrations.

Although the stable Cd concentrations used in these experiments were high $\left(20 \mu \mathrm{g} \mathrm{l}^{-1}\right)$, they may be representative of extremely contaminated marine areas. For example, Ward (1984) reported Cd concentrations of $11.5 \pm 19.6 \mathrm{\mu g} \mathrm{I}^{-1}$ in sea water flowing above the Posidonia australis meadows of First Creek (Spencer Gulf, South Australia) which is situated near the lead smelter at Port Pirie. During the same period, Cd concentrations up to $100 \mu \mathrm{g} \mathrm{g}^{-1}$ wet wt were measured in $P$. australis leaves (Ward 1987). In such a Cd contaminated environment, a feeding effect which interferes with $\mathrm{Cd}$ uptake from sea water might represent an adaptative advantage for the echinoids. Indeed, ingestion of Posidonia oceanica (i.e. the main echinoid food in the ecosystem considered) would presumably enhance excretion, mucus production, and coelom depurative activity. This would result in a reduction of direct $\mathrm{Cd}$ absorption from sea water which, like for many benthic invertebrates, is the main route for $\mathrm{Cd}$ bioaccumulation in Paracentrotus lividus (Bouquegneau \& Joiris 1988, Depledge \& Rainbow 1990, Warnau et al. 1995). Further research is needed to determine if the reduction of $\mathrm{Cd}$ absorption from sea water demonstrated in this study could be triggered by other food types (e.g. algae, detritus) which $P$. lividus ingests in other habitats.

Acknowledgements. We thank Prof. Jangoux, Ali Temara and Dimdim Deheyn (Free University of Brussels, Belgium) for a critical reading of the manuscript, and the crew of $R V$ 'Physalie' for their help in sampling. This research was partially supported by a fellowship from the European Science Foundation (ref. RF/94/53/E) and an IRSIA grant (ref. 910528) to M.W., by SILT n.v., and by the 'Fondation Louis Henry' a.s.b.l. Contribution of the 'Centre Interuniversitaire de Biologie Marine' (CIBIM). The IAEA Marine Environment Laboratory operates under a bipartite agreement between the International Atomic Energy Agency and the Government of the Principality of Monaco.

\section{LITERATURE CITED}

Besten den PJ, Bosma PT, Herwig HJ, Zandee DI, Voogt PA. (1991) Effects of cadmium on metal composition and adenylate energy charge in the sea star Asterias rubens L. Archs environ Contam Toxicol 21:112-117

Borchardt T (1.983) Influence of food quantity on the kinetics of cadmium uptake and loss via food and seawater in Mytilus edulis. Mar Biol 76:67-76

Bouquegneau JM, Joiris C (1988) The fate of stable pollutants - heavy metals and organochlorines - in marine organisms. In: Gilles R (ed) Advances in comparative and environmental physiology, Vol 2. Springer-Verlag, Berlin, p 219-247

Bremer PJ, Barker MF, Loutit MW (1990) A comparison of the roles of direct absorption and phytoplankton ingestion in 
accumulation of chromium by sea urchin larvae. Mar environ Res 30:233-241

Carvalho FP, Fowler SW (1994) A double-tracer technique to determine the relative importance of water and food as sources of polonium-210 to marine prawns and fish. Mar Ecol Prog Ser 103:251-264

Dance C (1987) Patterns of activity of the sea urchin Paracentrotus lividus in the Bay of Port-Cros (Var, France, Mediterranean). PSZN I: Mar Ecol 8:131-142

Depledge MH, Rainbow PS (1990) Models of regulation and accumulation of trace metals in marine invertebrates. Comp Biochem Physiol 97C:1-7

Fowler SW, Benayoun G, Parsi P, Essa MWA, Shulte EH (1981) Experimental studies on the bioavailability of technetium in selected marine organisms. In: Impacts of radionuclide releases into the marine environment. IAEA Publ, Vienna, p 319-339

Guary JC, Fowler SW, Beasley TM (1982) Routes of plutonium uptake and their relation to biomagnification in starfish. Mar Pollut Bull 13:99-102

Nakamura R, Nakahara M, Suzuki Y, Ueda T (1986) Relative importance of food and water in the accumulation of radionuclides by sea urchin Strongylocentrotus nudus. Bull Jap Soc Scient Fish 52:703-710

Nedelec H, Verlaque M (1984) Alimentation de l'oursin Paracentrotus lividus (Lamarck) dans un herbier à Posidonia oceanica (L.) Delile en Corse (Méditerranée-France). In:

This note was submitted to the editor
Boudouresque CF, Jeudy de Grissac A, Olivier J (eds) International workshop on Posidonia beds. GIS Posidonie Publ, Marseille, p 349-364

Nolan CV, Fowler SW, Teyssié JL (1992) Cobalt speciation and bioavailability in marine organisms. Mar Ecol Prog Ser 88:105-116

Pelletier E, Larocque R (1987) Bioaccumulation of mercury in starfish from contaminated mussels. Mar Pollut Bull 18: $482-485$

Phillips DJH (1976)The common mussel Mytilus edulis as an indicator of pollution by zinc, cadmium, lead and copper. I. Effects of environmental variables on uptake of metals. Mar Biol 38:59-69

Ward TJ (1984) Role of acute metal toxicity in structuring seagrass fauna near a lead smelter. Mar Ecol Prog Ser 17: $117-124$

Ward TJ (1987) Temporal variation of metals in the seagrass Posidonia australis and its potential as a sentinel accumulator near a lead smelter. Mar Biol 95: 315-321

Warnau $M$, Ledent $G$, Temara $A$, Jangoux $M$, Dubois $\mathrm{Ph}$ (1995) Experimental cadmium contamination of the echinoid Paracentrotus lividus: influence of exposure mode and distribution of the metal in the organism. Mar Ecol Prog Ser 116:117-124

Zar JH (1984) Biostatistical analysis, 2nd edn. Prentice-Hall Int Ltd, Englewood Cliffs, NJ

Manuscript first received: January 23,1995

Revised version accepted: May 2, 1995 